\title{
Zinc and selenium as modulating factors of the anatomy and physiology of Billbergia zebrina (Bromeliaceae) during in vitro culture
}

\author{
J.P.R. MARTINS",+, A.F.C. SOUZA*, L.C.A. RODRIGUES**, P.C.S. BRAGA*, A.B.P.L. GONTIJO*, \\ and A.R. FALQUETO* \\ Department of Agrarian and Biological Sciences, Federal University of Espírito Santo, Litorâneo - 29932-540 \\ São Mateus, ES, Brazil ${ }^{*}$ \\ Faculty of Dentistry, Federal University of Alfenas, Centro - 37130-001 Alfenas, MG, Brazil ${ }^{* *}$
}

\begin{abstract}
Deleterious effects induced by high zinc ( $\mathrm{Zn}$ ) concentrations can be alleviated with selenium (Se) co-exposure. Therefore, we analyzed the morphophysiological changes of Billbergia zebrina in response to Zn and Se co-exposure. Plants were cultured in media containing three $\mathrm{Zn}$ concentrations $(0,30$, and $300 \mu \mathrm{M})$ combined with two Se concentrations $(0$ and $4 \mu \mathrm{M}$ ), for a total of six treatments. At $75 \mathrm{~d}$ of culture, the leaf anatomy, chlorophyll (Chl) $a$ fluorescence, and contents of photosynthetic pigments (Chl) and nutrients were analyzed. The total Chl content declined with rising $\mathrm{Zn}$ concentrations. Plants cultured with Se presented a decrease in the Chl $a / b$ ratio and greater total Chl content. Positive L- and K-bands were verified under Se absence and with 30 and $300 \mu \mathrm{M}$ Zn. Plants showed bioaccumulation capacity and tolerance to excess $\mathrm{Zn}$. Se acted as a modulator to alleviate the $\mathrm{Zn}$ stress.
\end{abstract}

Additional keywords: biomonitors; bromeliad; JIP test; plant anatomy.

\section{Introduction}

In recent decades, anthropogenic activities have caused the accumulation of heavy metals at toxic concentrations in the environment (Hou et al. 2019, Kumar et al. 2019). Heavy metals can accumulate in the soil or be transported as dust particles by the wind (Abbasi et al. 2017, Khademi et al. 2019, Kumar et al. 2019). Their increased concentration in the environment is a serious concern because the areas contaminated by them can directly and/or indirectly harm living beings. Therefore, many countries have established programs to monitor and control heavy metal contents (Sidhu et al. 2017, Chen et al. 2019). Heavy metals, such as cadmium $(\mathrm{Cd})$, copper $(\mathrm{Cu})$, nickel $(\mathrm{Ni})$, lead $(\mathrm{Pb})$, and zinc $(\mathrm{Zn})$ can influence the condition of plants in different ways (Sidhu 2016, Sidhu et al. 2017, Georgiadou et al. 2018, Singh et al. 2018). Nevertheless, some of them are vital elements for cell metabolism, such as $\mathrm{Cu}, \mathrm{Ni}$, and $\mathrm{Zn}$.

Zinc is a micronutrient required by plants, essential for enzymatic activities, electron transport chain, and growth and development, especially of higher plants. Consequently, Zn deficiency induces various severe symptoms, in particular reducing crop yields (Roosta et al. 2018, Paradisone et al. 2020). On the other hand, high concentrations of these micronutrients may cause negative effects due to oxidative stress (Tiecher et al. 2017, Sidhu et al. 2020). Exposure to high concentrations of $\mathrm{Zn}$ can increase contents of hydrogen peroxide $\left(\mathrm{H}_{2} \mathrm{O}_{2}\right)$ and malondialdehyde (MDA) as well as higher superoxide dismutase (SOD) and peroxidase (POD) activity (Jain et al. 2010, Tiecher et al. 2017). The toxic effects of higher amounts of $\mathrm{Zn}$ also include inhibition of growth and photosynthesis, altered water balance and nutrient assimilation, senescence, and cause plant death (Singh et al. 2016).

Excess $\mathrm{Zn}$ can impair the photosynthetic activity of the leaves, causing a reduction in the yield of PSII photochemistry and photodamage (Monnet et al. 2005). In contrast, some plant species have the ability to grow in Zn-contaminated areas due to high photosynthetic capacity

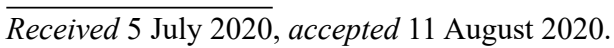

${ }^{+}$Corresponding author; phone: +55 273121 1696, e-mail: jprmartinss@yahoo.com.br

Abbreviations: Chl - chlorophyll; $\mathrm{F}_{\mathrm{v}}$ - variable fluorescence; OCE - oxygen-evolving complex; $\mathrm{PI}_{(\mathrm{ABS})}$ - performance index based on absorption; $\mathrm{PI}_{(\text {total }}$ - overall performance index, which measures the performance up until the final electron acceptors of PSI; $\mathrm{RC}$ - reaction center; $\mathrm{RC} / \mathrm{CS}_{0}$ - density of the active reaction centers; $\mathrm{SFI}_{(\mathrm{ABS})}$ - structure-function index; total Chl - total chlorophyll $(=\mathrm{Chl} a+\mathrm{Chl} b) ; \mathrm{V}_{\mathrm{I}}-$ relative variable fluorescence at $30 \mathrm{~ms}$ (point I); $\mathrm{V}_{\mathrm{J}}-$ relative variable fluorescence at $2 \mathrm{~ms}$ (point $\mathrm{J}$ ); $\mathrm{V}_{\mathrm{K}}-$ relative variable fluorescence at $0.3 \mathrm{~ms}$ (point $\mathrm{K}$ ); $\mathrm{W}_{\mathrm{K}}$ - represents the damage to $\mathrm{OEC} ; \mathrm{W}_{\mathrm{L}}$ - represents the changes in the fluidity of the thylakoid membrane and damages to its function and structural integrity; $\varphi_{\mathrm{D} 0}-$ quantum yield of energy dissipation; $\varphi_{\mathrm{E} 0}-$ quantum yield of electron transport; $\varphi_{\mathrm{P} 0}$ - maximum quantum yield of primary photochemistry; $\varphi_{\mathrm{R} 0}$ - quantum yield of reduction of end electron acceptors at the PSI acceptor side; $\psi_{0}$ - probability that a trapped exciton moves an electron into the electron transport chain beyond $\mathrm{Q}_{\mathrm{A}}^{-}$. Acknowledgments: The authors would like to acknowledge the scholarship awarded by the CNPq (Brazilian National Council for Scientific and Technological Development), the CAPES (Coordination for the Improvement of Higher Education Personnel), and the FAPES (Espírito Santo State Research Foundation).
} 
in the presence of excessive $\mathrm{Zn}$ concentrations (Andrejić et al. 2018).

The negative effects induced by heavy metals can be alleviated by a co-exposure to some mineral elements, such as selenium (Se) and silicon (Si) (Pereira et al. 2018, Paradisone et al. 2020). The use of Se, at low concentrations, can play a positive role in plants by promoting growth, increasing mineral nutrition and photosynthetic pigment content, and inducing morphological changes against heavy metal toxicity (Handa et al. 2018, Yin et al. 2019a, Zhao et al. 2019). Although this element is considered nonessential for plants, it is considered beneficial to many species, including bromeliads (Haghighi et al. 2016, Souza et al. 2019). A previous report demonstrated the beneficial effects of Se at low concentrations on the photosynthetic apparatus performance of the bromeliad Billbergia zebrina (Souza et al. 2019). This can be attributed to the nutritional modulations induced by Se exposure.

Pollution levels can be monitored by analyzing plants that assimilate the heavy metals dispersed in the environment or present clear morphophysiological changes. The results of the analysis provide information about the quality of their environment. Some studies have already shown potential use of bromeliad species as biomonitors (Cardoso-Gustavson et al. 2016, Martins et al. 2016, Marques Junior et al. 2018, Benítez et al. 2019). A study carried out under in vitro conditions showed that the species B. zebrina and Aechmea blanchetiana, both belonging to the Bromeliaceae family, have the potential for biomonitoring of $\mathrm{Cu}$ (Martins et al. 2016, 2020). Therefore, their use for monitoring other heavy metals is promising.

In vitro culture techniques offer benefits in studies related to plant physiology since they permit isolating the effects of the heavy metal stress without any external environmental interference. Several studies have reported morphophysiological alterations of plants submitted to heavy metals under in vitro conditions (Martins et al. 2016, 2020; Rodrigues et al. 2017, Muszyńska et al. 2018). These authors verified such changes through histological analysis (plant anatomy), measurement of enzymatic activity of the antioxidant system, or performance of the photosynthetic apparatus. Chlorophyll (Chl) $a$ fluorescence measurements can be used to learn the stress level of plants through the performance of the photosynthetic apparatus, especially regarding PSII (Kalaji et al. 2017, 2018). Determining the nutrient content can also assist in this type of study (Aydoğan et al. 2017, Tiecher et al. 2017, Wu et al. 2020). The nutrient status can affect the photochemical process of photosynthesis as well as plants' growth and development (Kalaji et al. 2018).

In view of the foregoing, we hypothesized that: (1) the species under study is tolerant to excess $\mathrm{Zn}$, but $\mathrm{Zn}$ exposure impairs its photosynthetic capacity; (2) Zn induces anatomical and physiological changes in B. zebrina plants; (3) Se can modulate the nutritional status; and (4) Se acts as a modulator to alleviate $\mathrm{Zn}$ stress. Thus, our aim was to analyze the effects of $\mathrm{Zn}$ and Se co-exposure during in vitro cultivation of $B$. zebrina plants. In addition, we also checked the biomonitoring potential of this species.

\section{Materials and methods}

Plant material and Se and $\mathbf{Z n}$ exposure: Billbergia zebrina plants were previously propagated in vitro through the procedures described by Martins et al. (2015). To analyze the co-exposure effects of Se and $\mathrm{Zn}$ during in vitro culture, side shoots of $B$. zebrina were used as explants. The shoots were transferred to $268-\mathrm{ml}$ glass containers holding $50 \mathrm{ml}$ of $\mathrm{Zn}$-modified MS culture medium (Murashige and Skoog 1962) supplemented with $30 \mathrm{~g} \mathrm{~L}^{-1}$ sucrose and solidified with $3.5 \mathrm{~g} \mathrm{~L}^{-1}$ agar. The treatments consisted of three concentrations of $\mathrm{Zn}(0,30$, and $300 \mu \mathrm{M})$ combined with two concentrations of Se $(0$ and $4 \mu \mathrm{M})$, totaling six treatments. The treatment with no addition of either Se and $\mathrm{Zn}$ was considered the control. The Se concentrations were defined according to Souza et al. (2019). As $\mathrm{Zn}$ and Se sources, $\mathrm{ZnSO}_{4}$ and $\mathrm{Na}_{2} \mathrm{SeO}_{3}$ were chosen. The $\mathrm{pH}$ of the culture medium was adjusted to 5.8 before autoclaving at $120^{\circ} \mathrm{C}$ for $20 \mathrm{~min}$. After inoculation in a laminar flow chamber, the plant material was kept in a growth room for $75 \mathrm{~d}$ at a temperature of $26 \pm 2{ }^{\circ} \mathrm{C}$ and a photoperiod of $16 \mathrm{~h}$.

Growth analysis: To infer the growth of in vitro plants, 50 plants from each treatment were collected randomly, divided into ten samples, and weighed on a precision scale. Then the fresh mass (FM) of the shoots (aerial part) and roots was determined in grams per plant.

Photosynthetic pigments content: For the quantification of photosynthetic pigments, eight plants were used. The pigments were extracted with $30-39 \mathrm{mg}$ of leaf material (the third fully expanded leaf). The plant material was placed in test tubes containing $5 \mathrm{ml}$ of $80 \%$ acetone, kept at a temperature of $4{ }^{\circ} \mathrm{C}$ in the dark for $48 \mathrm{~h}$, followed by spectrophotometric analysis (Genesys ${ }^{\mathrm{TM}} 10 \mathrm{~S} \mathrm{UV}-\mathrm{Vis}$ spectrophotometer, Thermo Fisher Scientific, West Palm Beach, FL, USA). The absorbances were read at $\lambda=665$ (Chl $a$ ) and $645 \mathrm{~nm}$ (Chl b) (Arnon 1949). The photosynthetic pigment contents were expressed in $\mu \mathrm{g} \mathrm{g}^{-1}(\mathrm{FM}$ of leaf tissue).

Chl $\boldsymbol{a}$ fluorescence analysis: The transients of Chl $a$ fluorescence were measured after $75 \mathrm{~d}$ of co-exposure to $\mathrm{Zn}$ and Se. The analysis was performed in 12 plants per treatment using a portable fluorometer (Handy PEA, Hansatech Instruments Ltd., King's Lynn, Norfolk, UK) and the measurement procedures were based on Souza et al. (2019). The emission of transient fluorescence was then recorded from $1 \mu \mathrm{s}$ to $1 \mathrm{~s}$ with 120 fluorescence points. The fluorescence intensities were expressed as $\mathrm{F}_{0}$ (0.02 ms), $F_{L}(0.15 \mathrm{~ms}), F_{K}(0.3 \mathrm{~ms}) \mathrm{F}_{\mathrm{J}}(2 \mathrm{~ms}), \mathrm{F}_{\mathrm{I}}(30 \mathrm{~ms})$, and $F_{m}(300 \mathrm{~ms})$. The analyses of OJIP transients and the JIP test parameters were according to Strasser et al. (2004).

Leaf anatomy: The leaf anatomy was analyzed in five plants chosen randomly from each treatment. The samples were fixed/stored in 50\% ethanol. The cross sections and paradermal sections were obtained and stained and the measurement procedures were performed as described 
by Martins et al. (2019). The sections were viewed using a light microscope (L-2000A-Fluor, Bioval, São Paulo, Brazil), and images were captured with a Leica EC3 camera (Wetzlar, Germany). The stomatal density [0.1 $\mathrm{mm}^{2}$ and the number and diameter of xylem vessels $[\mu \mathrm{m}]$ were determined in leaves.

Mineral nutrient content: The mineral nutrient content in $B$. zebrina plants was analyzed at $75 \mathrm{~d}$ of growth. There were three repetitions per treatment, using only the aerial part (previously washed in distilled water and dried by forced air circulation at $70^{\circ} \mathrm{C}$ ). The contents of $\mathrm{N}, \mathrm{K}, \mathrm{Ca}$, $\mathrm{Mg}, \mathrm{Cu}, \mathrm{Mn}, \mathrm{S}$, and $\mathrm{Zn}$ were determined. The dried plant material was ground in a Wiley mill with 20 mesh sieve and digested in nitro-perchloric solution 2:1 (v/v) for the determination of $\mathrm{K}, \mathrm{Ca}, \mathrm{Mg}, \mathrm{Cu}, \mathrm{Mn}, \mathrm{S}$, and $\mathrm{Zn}$; and sulfuric acid solution for the determination of nitrogen $(\mathrm{N})$ by the micro Kjeldahl method (distillation). The contents of $\mathrm{N}, \mathrm{Ca}, \mathrm{Mg}, \mathrm{Cu}, \mathrm{Mn}$, and $\mathrm{Zn}$ were then determined by atomic absorption spectroscopy (AA-7000, Shimadzu, Tokyo, Japan); S content by UV-visible spectrophotometry (Biospectro SP-22 spectrophotometer, São Paulo, Brazil); and K content by flame photometry (B262, Micronal, São Paulo, Brazil) (Malavolta et al.1997).

Statistical analysis: The experimental design was completely randomized with a $2 \times 3$ factorial scheme: two Se concentrations $(0$ and $4 \mu \mathrm{M})$ and three $\mathrm{Zn}$ concentrations $(0,30$, and $300 \mu \mathrm{M})$. The resulting data were submitted to analysis of variance $(A N O V A)$ and the averages were compared using the Tukey's test $(p<0.05)$. All analyses were performed using the SISVAR software.

\section{Results}

Biomass accumulation: After $75 \mathrm{~d}$ of in vitro culture with excess $\mathrm{Zn}$, irrespective of Se supplementation, the plants did not show any mortality or visible physiological disturbances, such as chlorosis, necrosis, or leaf discoloration. However, both variation factors influenced biomass accumulation, but they acted independently. The fresh mass of roots increased as a function of $\mathrm{Zn}$ concentrations $\left(R^{2}=0.98\right)$. In contrast, the tested concentration range of $\mathrm{Zn}$ did not influence the shoot fresh mass. When comparing the $\mathrm{Se}$ treatments, irrespective of $\mathrm{Zn}$, the biomass of roots decreased and shoots increased with $4 \mu \mathrm{M}$ of Se supplementation (Fig. 1).

Photosynthetic pigments: The contents of pigments were also influenced by the treatments, but the factors ( $\mathrm{Zn}$ and Se concentrations) did not have significant interaction. The total Chl content decreased as a function of $\mathrm{Zn}$ concentrations, but there were no changes in the $\mathrm{Chl} a / b$ ratio. On the other hand, Se exposure induced a decrease in the $\mathrm{Chl} a / b$ ratio as well as increased the total $\mathrm{Chl}$ content (Fig. 2).

Chl fluorescence analysis: All plants remained photosynthetically active, irrespective of the applied treatment. Nevertheless, the relative variable fluorescence between the O- and P-steps presented a decrease at the K-step and J-step in all treatments with $4 \mu \mathrm{M}$ Se compared to Se absence. The $\mathrm{V}_{\mathrm{I}}$ did not change as a function of Se, but it increased when plants were exposed to Zn (Fig. $3 A, B$ ). Kinetic differences were also observed between steps $\mathrm{O}-\mathrm{K}$ and $\mathrm{O}-\mathrm{J}$. Positive L- and K-bands were verified under Se absence and with 30 and $300 \mu \mathrm{M} \mathrm{Zn}$. In addition, $\mathrm{W}_{\mathrm{L}}$ $\left[\mathrm{W}_{\mathrm{L}}=\left(\mathrm{F}_{\mathrm{L}}-\mathrm{F}_{0}\right) /\left(\mathrm{F}_{\mathrm{K}}-\mathrm{F}_{0}\right)\right]$ and $\mathrm{W}_{\mathrm{K}}\left[\mathrm{W}_{\mathrm{K}}=\left(\mathrm{F}_{\mathrm{K}}-\mathrm{F}_{0}\right) /\left(\mathrm{F}_{\mathrm{J}}-\mathrm{F}_{0}\right)\right]$ were lower when plants were cultured with Se (Fig. 3C,D).

The JIP test showed changes in the photosynthetic apparatus as a function of both $\mathrm{Zn}$ and Se. This influence of both factors was independent (without a significant interaction of the variation factors) for most parameters. When the plants were cultured with $300 \mu \mathrm{M} \mathrm{Zn}$, they presented reduced $\mathrm{F}_{\mathrm{v}}$ and $\mathrm{RC} / \mathrm{CS}_{0}$ values, independently of the Se concentration. In contrast, plants grown in

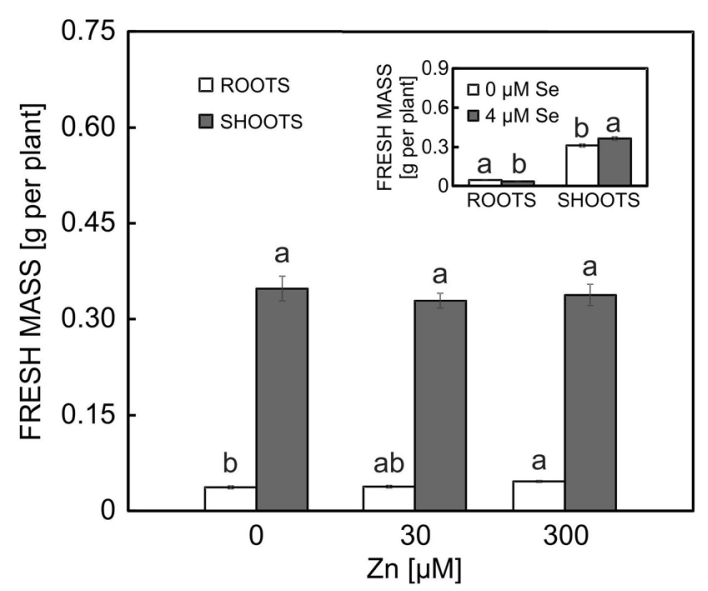

Fig. 1. Fresh mass [g per plant] of shoots (aerial parts) and roots of Billbergia zebrina plants at 75 days of in vitro growth as a function of $\mathrm{Zn}[\mu \mathrm{M}]$ and $\mathrm{Se}[\mu \mathrm{M}]$ concentrations. For each growth trait, means $\pm \mathrm{SE}(n=10)$ followed by the same letter do not differ significantly according to the Tukey's test $(p<0.05)$.

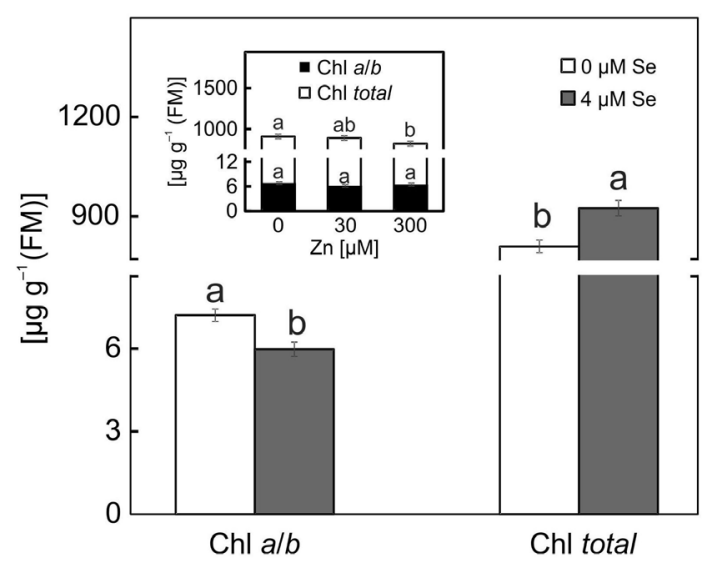

Fig. 2. Chlorophyll content and $\mathrm{Chl} a / b$ ratio $\left[\mu \mathrm{g} \mathrm{g} \mathrm{g}^{-1}(\mathrm{FM})\right]$ of Billbergia zebrina plants as a function of $\mathrm{Zn}[\mu \mathrm{M}]$ and $\mathrm{Se}[\mu \mathrm{M}]$ concentrations during in vitro culture. For each trait, means \pm $\mathrm{SE}(n=8)$ followed by the same letter do not differ significantly according to the Tukey's test $(p<0.05)$. FM - fresh mass. 

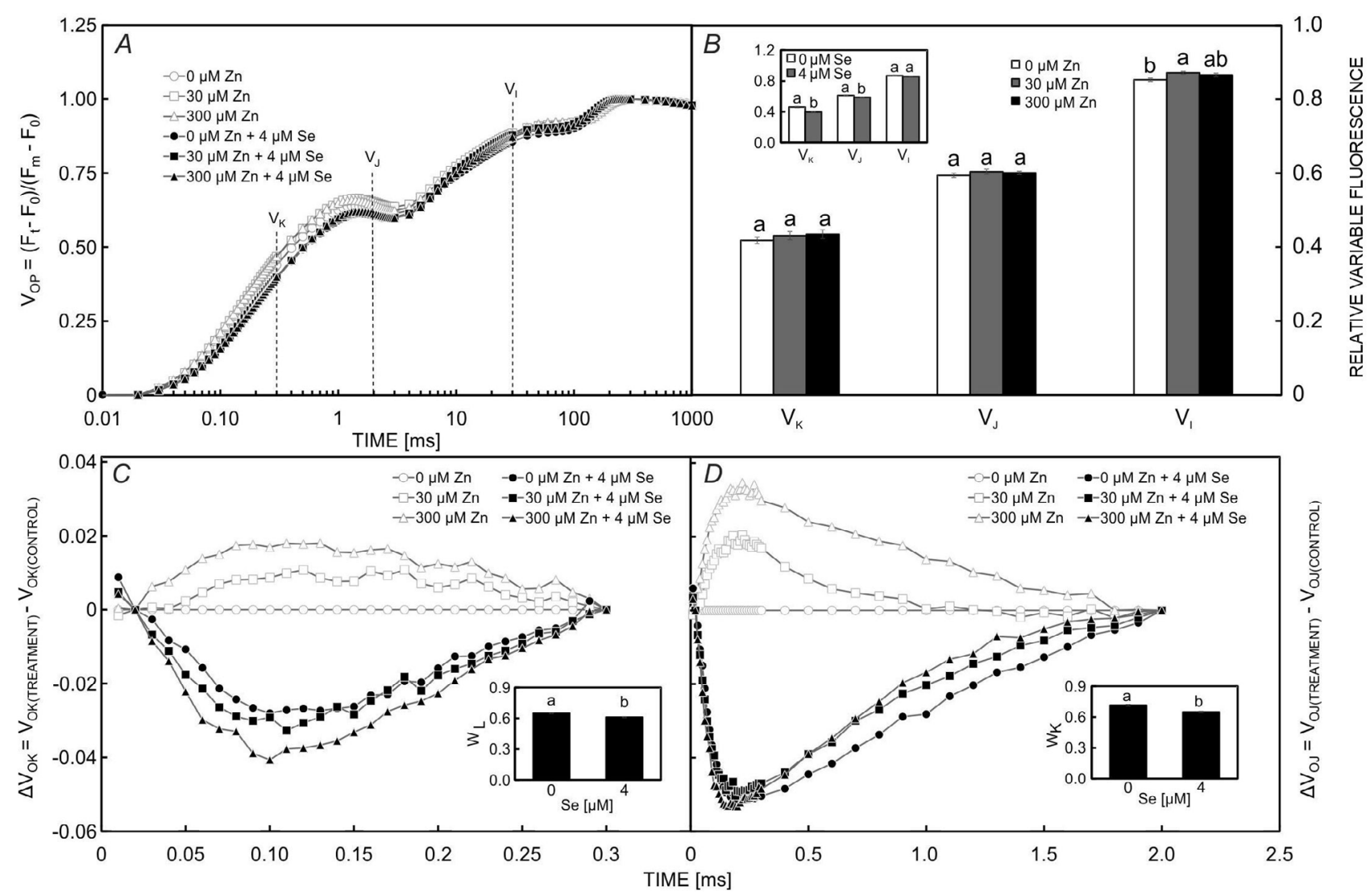

Fig. 3. Relative variable fluorescence and kinetic differences of Billbergia zebrina plants grown in media with different $\mathrm{Zn}[\mu \mathrm{M}]$ and $\mathrm{Se}[\mu \mathrm{M}]$ concentrations. Relative variable fluorescence between $\mathrm{F}_{0}$ and $\mathrm{F}_{\mathrm{M}}\left(\mathrm{V}_{\mathrm{OP}}\right)(A)$; relative variable fluorescence at phases $\mathrm{K}$, $\mathrm{J}$, and $\mathrm{I}(B)$; kinetic differences between steps $\mathrm{O}$ and $\mathrm{K}\left[\mathrm{V}_{\mathrm{OK}}=\left(\mathrm{F}_{\mathrm{t}}-\mathrm{F}_{0}\right) /\left(\mathrm{F}_{\mathrm{K}}-\mathrm{F}_{0}\right)\right]$, showing the L-band $(C)$; kinetic differences between steps $\mathrm{O}$ and $\mathrm{J}\left[\mathrm{V}_{\mathrm{OJ}}=\left(\mathrm{F}_{\mathrm{t}}-\mathrm{F}_{0}\right) /\left(\mathrm{F}_{\mathrm{J}}-\mathrm{F}_{0}\right)\right]$, showing the $\mathrm{K}$-band $(D)$. For each parameter, means $\pm \mathrm{SE}(n=12)$ followed by the same letter do not differ significantly according to the Tukey's test $(p<0.05)$. $\mathrm{V}_{\mathrm{I}}-$ relative variable fluorescence at $30 \mathrm{~ms}$ (point I); $\mathrm{V}_{\mathrm{J}}-$ relative variable fluorescence at $2 \mathrm{~ms}$ (point $\mathrm{J}$ ); $\mathrm{V}_{\mathrm{K}}$ - relative variable fluorescence at $0.3 \mathrm{~ms}$ (point $\mathrm{K}$ ); $\mathrm{W}_{\mathrm{K}}$ - damages to $\mathrm{OEC}$; $\mathrm{W}_{\mathrm{L}}-$ changes in the fluidity of the thylakoid membrane and damages to its functional and structural integrity.

medium supplemented with $4 \mu \mathrm{M}$ Se, irrespective of $\mathrm{Zn}$ concentration, had higher values of $\psi_{0}, \varphi_{\mathrm{E} 0}, \varphi_{\mathrm{R} 0}, \mathrm{SFI}_{(\mathrm{ABS})}$, and $\mathrm{PI}_{(\mathrm{ABS})}$ compared to those cultured in Se-free medium (Fig. 4, Table 1).

The parameters related to quantum yield of primary photochemistry $\left(\varphi_{\mathrm{P} 0}\right)$ and dissipation $\left(\varphi_{\mathrm{D} 0}\right)$, as well as overall performance index $\left[\mathrm{PI}_{(\text {total }}\right]$ interacted significantly to both $\mathrm{Zn}$ and Se concentrations. Plants cultured without Se had similar values of $\varphi_{\mathrm{P} 0}$ and $\varphi_{\mathrm{D} 0}$. On the other hand, when the media were supplemented with Se, plants showed increased $\varphi_{\mathrm{P} 0}$ and decreased $\varphi_{\mathrm{D} 0}$ as a function of $\mathrm{Zn}$ concentrations. When comparing the two Se concentrations at each $\mathrm{Zn}$ concentration, plants grown with Se exhibited higher $\varphi_{\mathrm{P} 0}$ and lower $\varphi_{\mathrm{D} 0}$. Likewise, under $4 \mu \mathrm{M}$ Se exposure, the $\mathrm{PI}_{\text {(total) }}$ values were similar for the $\mathrm{Zn}$ concentrations and higher than that under Se-absence treatment. Also, plants cultured without Se showed decreased $\mathrm{PI}_{(\text {total }}$ as a function of rising $\mathrm{Zn}$ concentrations (Fig. 5).

Leaf anatomy: All anatomical traits are shown in Fig. $6 A-F$. Stomatal density was influenced by both factors.
In media without Se addition, the leaves had a larger number of stomata, while in the presence of Se, the number of stomata per area was similar, regardless of the $\mathrm{Zn}$ concentration. Among the concentrations of $\mathrm{Zn}$, only $0 \mu \mathrm{M} \mathrm{Zn}+0 \mu \mathrm{M}$ Se (control) produced a lower stomatal density (Fig. 6G). Concerning the xylem traits, the number of vessels was similar in all treatments, but the diameter of xylem vessels was larger in leaves of Se-treated plants (Fig. 6H).

Nutrient content: The contents of nutrients analyzed were influenced by the treatments, but Se and $\mathrm{Zn}$ acted separately (Table 2). The high Zn supplementation showed a clear negative effect regarding $\mathrm{N}, \mathrm{Mn}$, and $\mathrm{Cu}$ contents. The contents of these nutrients decreased at $300 \mu \mathrm{M} \mathrm{Zn}$. In contrast, the content of $\mathrm{Zn}$ increased as a function of $\mathrm{Zn}$ concentrations in the media. When analyzing the nutrient contents as a function of Se concentrations, the contents of $\mathrm{N}, \mathrm{K}, \mathrm{Ca}, \mathrm{Mg}, \mathrm{Mn}$, and $\mathrm{Zn}$ were statistically similar, but the contents of $\mathrm{S}$ and $\mathrm{Cu}$ were lower in plants cultured with $4 \mu \mathrm{M}$ Se in comparison with plants cultured in Se-free media. 


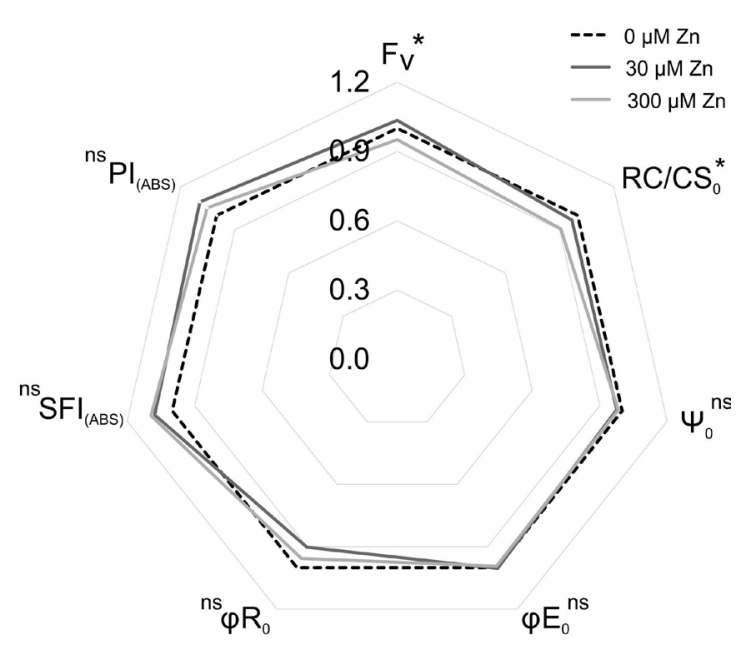

Fig. 4. The JIP test parameters of Billbergia zebrina plants grown as a function of $\mathrm{Zn}[\mu \mathrm{M}]$ concentrations. Means $\pm \mathrm{SE}(n=12)$ followed by an asterisk $(*)$ are significantly different according to the Tukey's test $(p<0.05) . \mathrm{F}_{\mathrm{v}}-$ variable fluorescence; $\mathrm{PI}_{(\mathrm{ABS})}-$ performance index based on absorption; $\mathrm{RC} / \mathrm{CS}_{0}$ - density of the active reaction centers; $\mathrm{SFI}_{(\mathrm{ABS})}$ - structure-function index; $\varphi_{\mathrm{E} 0}-$ quantum yield of electron transport; $\varphi_{\mathrm{R} 0}-$ quantum yield of reduction of end electron acceptors at the PSI acceptor side; $\psi_{0}$ - probability that a trapped exciton moves an electron into the electron transport chain beyond $\mathrm{Q}_{\mathrm{A}}{ }^{-}$.

Table 1. JIP test parameters as a function of Se $[\mu \mathrm{M}]$ concentrations obtained based on chlorophyll $a$ fluorescence of in vitro grown Billbergia zebrina plants. Means \pm SE $(n=12)$ accompanied by different letters in the same row are significantly different by the Tukey's test $(p<0.05) . \mathrm{F}_{\mathrm{v}}-$ variable fluorescence; $\mathrm{PI}_{(\mathrm{ABS})}$ - performance index based on absorption; $\mathrm{RC} / \mathrm{CS}_{0}-$ density of the active reaction centers; $\mathrm{SFI}_{(\mathrm{ABS})}$ - structure-function index; $\varphi_{\mathrm{E} 0}-$ quantum yield of electron transport; $\varphi_{\mathrm{R} 0}-$ quantum yield of reduction of end electron acceptors at the PSI acceptor side; $\psi_{0}$ - probability that a trapped exciton moves an electron into the electron transport chain beyond $\mathrm{Q}_{\mathrm{A}^{-}}$.

\begin{tabular}{lll}
\hline Parameter & \multicolumn{2}{l}{ Se concentration $[\mu \mathrm{M}]$} \\
& 0 & 4 \\
\hline $\mathrm{F}_{\mathrm{v}}$ & $1,758.14 \pm 28.37^{\mathrm{a}}$ & $1,727.64 \pm 26.40^{\mathrm{a}}$ \\
$\mathrm{RC} / \mathrm{CS}_{0}$ & $234.98 \pm 3.54^{\mathrm{a}}$ & $232.23 \pm 3.05^{\mathrm{a}}$ \\
$\psi_{0}$ & $0.387 \pm 0.004^{\mathrm{b}}$ & $0.413 \pm 0.004^{\mathrm{a}}$ \\
$\varphi_{\mathrm{E} 0}$ & $0.253 \pm 0.004^{\mathrm{b}}$ & $0.284 \pm 0.004^{\mathrm{a}}$ \\
$\varphi_{\mathrm{R} 0}$ & $0.085 \pm 0.003^{\mathrm{b}}$ & $0.091 \pm 0.001^{\mathrm{a}}$ \\
$\mathrm{SFI}_{(\mathrm{ABS})}$ & $0.061 \pm 0.002^{\mathrm{b}}$ & $0.072 \pm 0.001^{\mathrm{a}}$ \\
$\mathrm{PI}_{(\mathrm{ABS})}$ & $2.29 \pm 0.27^{\mathrm{b}}$ & $3.70 \pm 0.14^{\mathrm{a}}$ \\
\hline
\end{tabular}

\section{Discussion}

In this study, we reported the effects of excess $\mathrm{Zn}$ and $\mathrm{Se}$ during the in vitro growth of $B$. zebrina. Both elements individually acted as modulating factors of the plants' anatomy and physiology. However, we also found that Se can alleviate the physiological stress of $B$. zebrina plants under excessive $\mathrm{Zn}$ exposure.

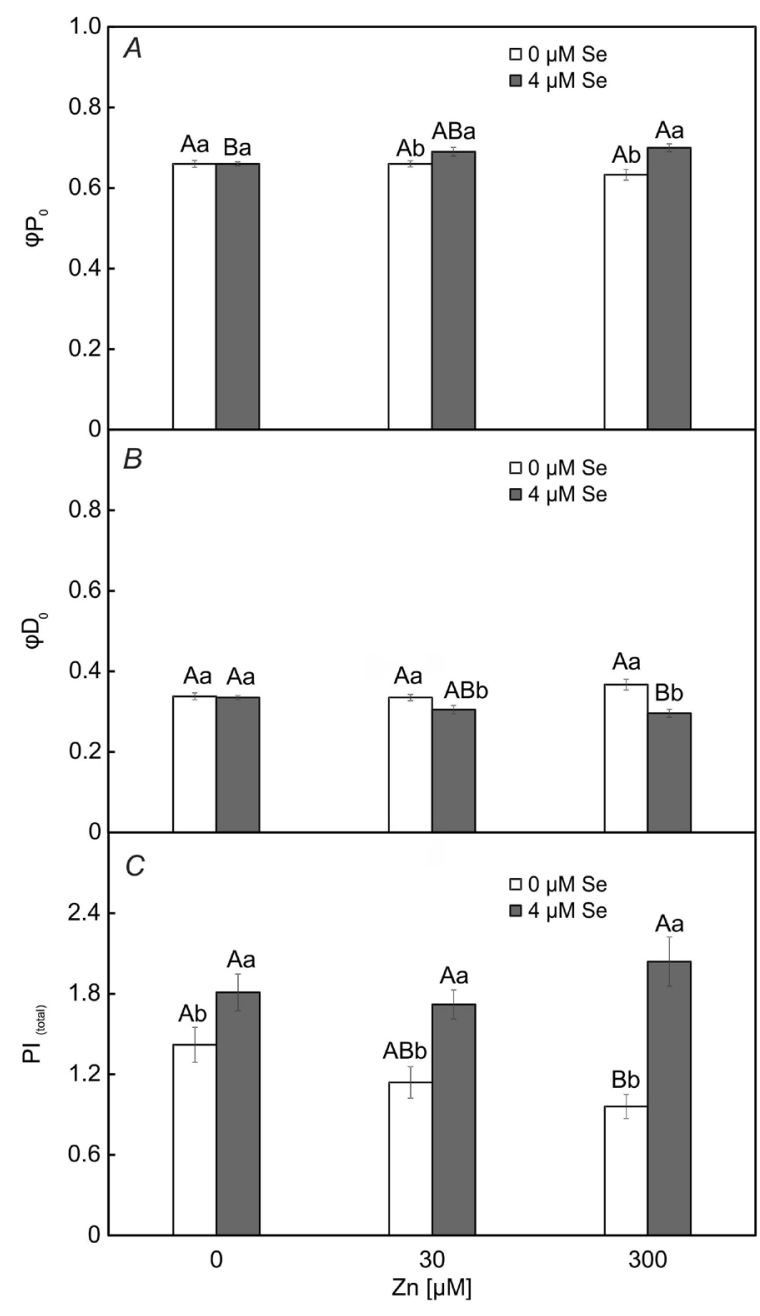

Fig. 5. Photochemical parameters derived from the analysis of the JIP test of Billbergia zebrina plants grown in media with different $\mathrm{Zn}[\mu \mathrm{M}]$ and Se $[\mu \mathrm{M}]$ concentrations. Means \pm SE $(n=12)$ followed by the same letter (uppercase at each Se concentration - comparing the $\mathrm{Zn}$ concentrations; and lowercase at each $\mathrm{Zn}$ concentration - comparing the two Se concentrations) do not differ significantly according to the Tukey's test $(p<0.05)$. $\mathrm{PI}_{(\text {total })}-$ overall performance index, which measures the performance up until the final electron acceptors of PSI; $\varphi_{\mathrm{D} 0}$ - quantum yield of energy dissipation; $\varphi_{\mathrm{P} 0}-$ maximum quantum yield of primary photochemistry.

The conditions imposed during in vitro cultivation altered the plants' morphology. The exposure to excess $\mathrm{Zn}$ induced plants with a higher root fresh mass. Similarly, Giampaoli et al. (2012) and Zampieri et al. (2012) verified an increase of biomass accumulation of roots in a bromeliad species under in vitro conditions. In our work, this response was linked to a higher number of roots per plant, even though the roots were shorter. Plants can increase the number of roots to allow them to explore a larger area in the medium (Martins et al. 2016). Changes in the root architecture may be a response to metals, acting as a heavy-metal 'escape' strategy aimed at recruiting metal-free fragments (Bochicchio et al. 2015). On the 


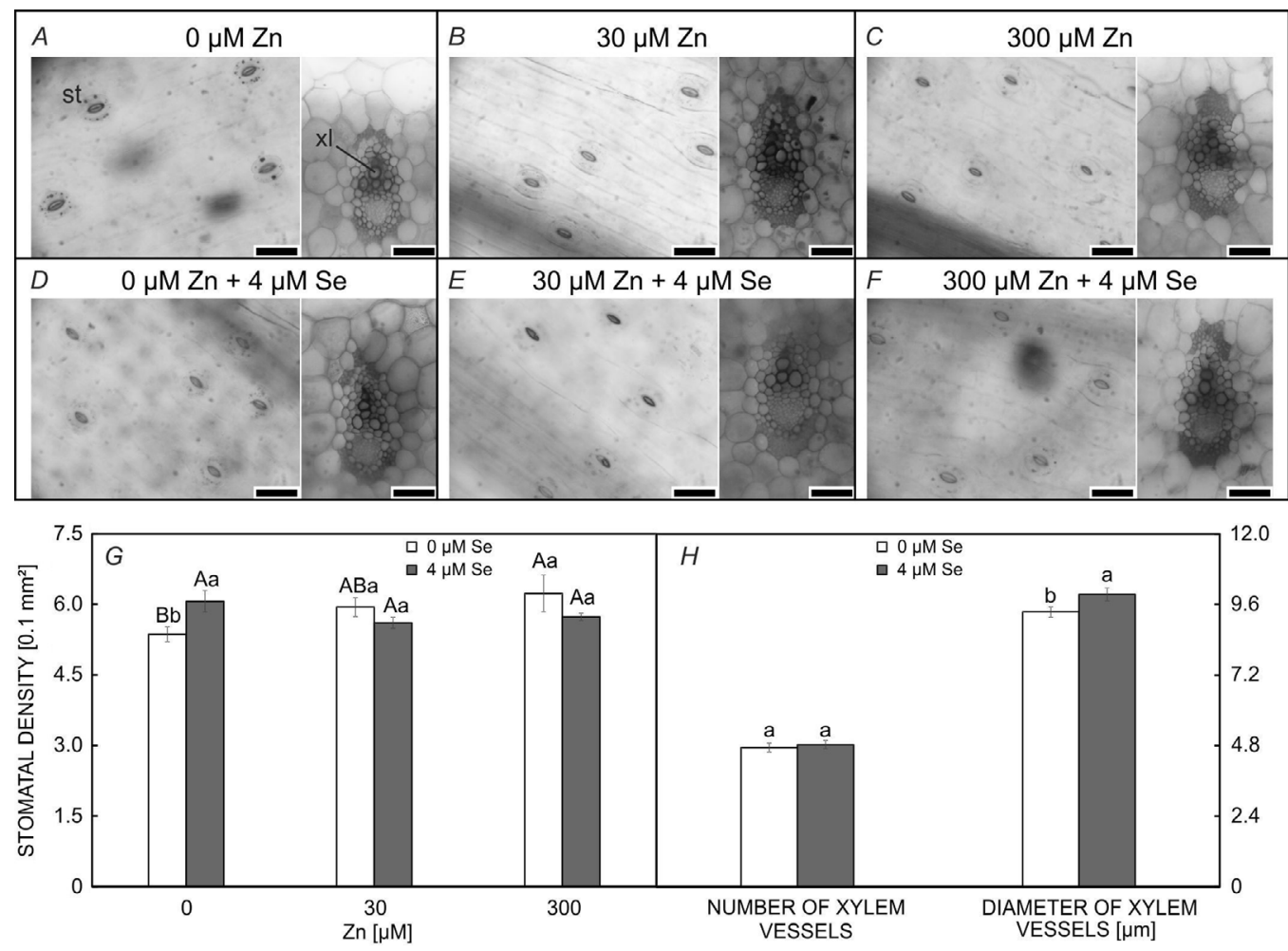

Fig. 6. Anatomical traits of Billbergia zebrina leaves of plants grown in vitro as a function of $\mathrm{Se}[\mu \mathrm{M}]$ and $\mathrm{Zn}[\mu \mathrm{M}]$ concentrations. Paradermal sections and cross-sections of Billbergia zebrina's leaves as a function of the $\mathrm{Se}(0$ and $4 \mu \mathrm{M})$ and $\mathrm{Zn}(0,30$, and $300 \mu \mathrm{M})$ concentrations during in vitro culture $(A-F)$. Bar $=100 \mu \mathrm{m}$. st - stoma; $\mathrm{xl}-\mathrm{xylem}$. Stomatal density as a function of Se and $\mathrm{Zn}$ treatments $(G)$. Number and diameter of xylem vessels as a function of two Se levels $(H)$. For each trait, means $\pm \operatorname{SE}(n=5)$ followed by the same letter do not differ significantly according to the Tukey's test $(p<0.05)$. Means $\pm \operatorname{SE}(n=5)$ followed by the same letter (uppercase at each Se concentration - comparing the $\mathrm{Zn}$ concentrations; and lowercase at each $\mathrm{Zn}$ concentration - comparing the two Se concentrations) do not differ significantly according to the Tukey's test $(p<0.05)$.

Table 2. Nutrient contents of Billbergia zebrina plants as a function of $\mathrm{Se}[\mu \mathrm{M}]$ or $\mathrm{Zn}[\mu \mathrm{M}]$ concentrations during in vitro growth. Means \pm SE $(n=3)$ accompanied by different letters in the same row are significantly different by the Tukey's test $(p<0.05)$. $\mathrm{Ca}$ - calcium; $\mathrm{Cu}$ - copper; $\mathrm{K}$ - potassium; $\mathrm{Mg}$ - magnesium; $\mathrm{Mn}$ - manganese; $\mathrm{N}$ - nitrogen; $\mathrm{S}$ - sulfur; $\mathrm{Zn}$ - zinc.

\begin{tabular}{|c|c|c|c|c|c|}
\hline \multirow[t]{2}{*}{ Nutrients } & \multicolumn{2}{|c|}{ Se concentration $[\mu \mathrm{M}]$} & \multicolumn{3}{|c|}{ Zn concentration $[\mu \mathrm{M}]$} \\
\hline & 0 & 4 & 0 & 30 & 300 \\
\hline $\mathrm{N}[\%]$ & $4.47 \pm 0.11^{\mathrm{a}}$ & $4.46 \pm 0.14^{\mathrm{a}}$ & $4.57 \pm 0.16^{\mathrm{ab}}$ & $4.70 \pm 0.12^{\mathrm{a}}$ & $4.13 \pm 0.07^{b}$ \\
\hline $\mathrm{K}[\%]$ & $4.09 \pm 0.09^{\mathrm{a}}$ & $4.01 \pm 0.06^{\mathrm{a}}$ & $3.96 \pm 0.04^{\mathrm{a}}$ & $4.20 \pm 0.12^{\mathrm{a}}$ & $3.98 \pm 0.07^{\mathrm{a}}$ \\
\hline $\mathrm{Ca}[\%]$ & $0.57 \pm 0.02^{\mathrm{a}}$ & $0.56 \pm 0.01^{\mathrm{a}}$ & $0.53 \pm 0.01^{\mathrm{a}}$ & $0.60 \pm 0.02^{\mathrm{a}}$ & $0.56 \pm 0.02^{\mathrm{a}}$ \\
\hline $\operatorname{Mg}[\%]$ & $0.21 \pm 0.01^{\mathrm{a}}$ & $0.21 \pm 0.01^{\mathrm{a}}$ & $0.22 \pm 0.01^{\mathrm{a}}$ & $0.21 \pm 0.01^{\mathrm{a}}$ & $0.20 \pm 0.02^{\mathrm{a}}$ \\
\hline $\mathrm{S}[\%]$ & $0.34 \pm 0.01^{\mathrm{a}}$ & $0.30 \pm 0.01^{\mathrm{b}}$ & $0.30 \pm 0.01^{\mathrm{a}}$ & $0.33 \pm 0.01^{\mathrm{a}}$ & $0.32 \pm 0.02^{\mathrm{a}}$ \\
\hline $\mathrm{Cu}[\mathrm{ppm}]$ & $2.52 \pm 0.27^{\mathrm{a}}$ & $1.86 \pm 0.14^{b}$ & $1.90 \pm 0.18^{\mathrm{b}}$ & $2.87 \pm 0.31^{\mathrm{a}}$ & $1.81 \pm 0.16^{\mathrm{b}}$ \\
\hline $\mathrm{Mn}[\mathrm{ppm}]$ & $230.03 \pm 7.64^{\mathrm{a}}$ & $214.15 \pm 9.89^{\mathrm{a}}$ & $243.70 \pm 4.86^{\mathrm{a}}$ & $224.98 \pm 7.93^{\mathrm{ab}}$ & $197.59 \pm 10.55^{b}$ \\
\hline $\mathrm{Zn}[\mathrm{ppm}]$ & $135.36 \pm 37.87^{\mathrm{a}}$ & $132.30 \pm 35.11^{\mathrm{a}}$ & $39.58 \pm 2.45^{\mathrm{c}}$ & $85.48 \pm 3.95^{\mathrm{b}}$ & $276.43 \pm 8.41^{\mathrm{a}}$ \\
\hline
\end{tabular}

other hand, Se exposure had a positive effect on the fresh mass of B. zebrina shoots. The Se application can increase the biomass accumulation of many plant species, as well as alleviate abiotic stress, such as that caused by salt and heavy metals (Ashraf et al. 2018, Souza et al. 2019, Yin et al. 2019a). According to Souza et al. (2019), low concentrations of Se can increase plant growth due to enhanced photosynthetic apparatus performance. Our findings corroborate that observation.

The present study revealed the physiological stress induced by excess $\mathrm{Zn}$ on photosynthetic pigment contents. The stress level of plants can be inferred by analyzing the photosynthetic pigment content because it usually decreases under stress conditions (Martins et al. 2018, Souza et al. 2020). A reduction of Chl content may be associated with degradation due to oxidative stress (Santos 
et al. 2020, Sidhu et al. 2020). Indeed, under Zn stress, alterations of the enzymatic and nonenzymatic status of the antioxidant system have been reported (Bernardy et al. 2020, Santos et al. 2020, Sidhu et al. 2020). Nevertheless, the different $\mathrm{Zn}$ concentrations did not change the $\mathrm{Chl} a / b$ ratio. The adjustments in the anatomy and/or physiology can counteract the deleterious effects of excess heavy metals, which is confirmed by the absence of changes in the $\mathrm{Chl} a / b$ ratio (Martins et al. 2020). Normally, under heavy metal stress plants show signs of physiological damages induced by the metals' toxicity, such as reduced $\mathrm{Chl} a / b$ ratio along with the reduced total $\mathrm{Chl}$ content, indicating an imbalance in the contents of photosynthetic pigments (Aydoğan et al. 2017). This response indicates that the heavy metals have a negative effect on Chl $a$ content (Houri et al. 2020). Still concerning the photosynthetic pigments, Se had a positive effect on Chl contents. The lower $\mathrm{Chl} a / b$ ratio along with the increased total $\mathrm{Chl}$ led to improved photosynthetic apparatus performance, as evidenced by the $\mathrm{PI}_{(\mathrm{ABS})}$ and $\mathrm{PI}_{(\text {total })}$ values.

Further analysis confirmed the positive effects of Se on physiological status, as well as that excess $\mathrm{Zn}$ can influence the photosynthetic apparatus of $B$. zebrina. The improvement in the electron transport chain was pronounced in plants cultured with Se. The $\mathrm{V}_{\mathrm{K}}, \mathrm{W}_{\mathrm{K}}$, and $V_{J}$ values can characterize the performance of the watersplitting system of PSII and electron flow from quinone $\mathrm{A}\left(\mathrm{Q}_{\mathrm{A}}\right)$ to quinone $\mathrm{B}\left(\mathrm{Q}_{\mathrm{B}}\right)$ (Chen et al. 2015, Zhang et al. 2018, Yin et al. 2019b). The lower $\mathrm{V}_{\mathrm{K}}, \mathrm{W}_{\mathrm{K}}$, and $\mathrm{V}_{\mathrm{J}}$ values observed in plants cultured with Se indicated enhanced oxygen-evolving complex (OEC) activity at the electron donor side of PSII and an optimized rate of electron transport between $\mathrm{Q}_{\mathrm{A}}$ and $\mathrm{Q}_{\mathrm{B}}$, which means an increase in primary photochemical activity.

Although the positive L- and K-bands were observed in plants under Se absence and with 30 and $300 \mu \mathrm{M}$ of $\mathrm{Zn}$, the $\mathrm{W}_{\mathrm{L}}$ and $\mathrm{W}_{\mathrm{K}}$ values indicated a clear distinction between Se treatments ( 0 and $4 \mu \mathrm{M} \mathrm{Se})$. Higher $\mathrm{W}_{\mathrm{L}}$ values denote lower functional and structural integrity of the thylakoid membranes (Zhang et al. 2018). Likewise, increased $\mathrm{W}_{\mathrm{K}}$ values may indicate partial damage to electron transport from OEC to $\mathrm{P}_{680}{ }^{+}$(Wang et al. 2016). In this study, B. zebrina plants cultured without Se had a lower performance of thylakoid membranes and OEC efficiency on the donor side of PSII. In addition, the negative L- and K-bands appeared in plants in medium with $\mathrm{Se}$ and it pointed to improved energy absorption and connectivity between PSII units.

The higher $F_{v}$ values of plants also confirmed the enhanced dynamic structure of thylakoid architecture. A decline in $\mathrm{F}_{\mathrm{v}}$ values can indicate damage to the thylakoid structure and direct impairment in the reaction centers (RCs) (Kalaji et al. 2016, Sha et al. 2019). Thus, the decreased values of $\mathrm{F}_{\mathrm{v}}$ and $\mathrm{RC} / \mathrm{CS}_{0}$ verified in plants cultured with $300 \mu \mathrm{M} Z n$ mean that excess $\mathrm{Zn}$ can cause damages, leading to the interconversion of active RCs into inactive ones. Inactivation of a part of the RCs of PSII leads to higher energy dissipation ('energy sinks'), thus transforming the excitation energy of the antenna chlorophylls into heat energy (Paunov et al. 2018). The heat dissipation through this photoprotective mechanism induced by excess $\mathrm{Zn}$ stress was indicated by the $\varphi_{\mathrm{D} 0}$ value. There was a reduction of PSII efficiency, demonstrated by $\varphi_{\mathrm{P} 0}$ values, which can be attributed to the insufficient energy transfer from the light-harvesting complex to the reaction center of Chl molecules (Sha et al. 2019). In this study, Se acted against the stress caused by excess $\mathrm{Zn}$, efficiently assuring better photosynthetic performance (higher values of $\varphi_{\mathrm{P} 0}$ and $\left.\mathrm{PI}_{(\text {total) }}\right)$ due to lower energy loss by nonphotochemical energy dissipation $\left(\varphi_{\mathrm{D} 0}\right)$.

The parameters related to electron transport were influenced by Se exposure. The increased values of $\psi_{0}$ and $\varphi_{\mathrm{E} 0}$ as well as $\varphi_{\mathrm{P} 0}$ in plants cultured with $4 \mu \mathrm{M}$ Se pointed to enhanced electron flow from PSII to PSI and enhanced $\mathrm{Q}_{\mathrm{A}}^{-}$reoxidation due to higher diffusion of plastoquinone (PQ) across the thylakoid membrane (Singh et al. 2018), as already indicated by the lower $\mathrm{W}_{\mathrm{L}}$ values, pointing to higher functionality of the thylakoid membranes. The improved structure and function of PSII in plants cultured with Se were confirmed by the structure-function index $\left[\mathrm{SFI}_{(\mathrm{ABS})}\right]$. Increments in $\mathrm{SFI}_{(\mathrm{abs})}$ can indicate a reduction in energy dissipated as heat and fluorescence, which may be linked to an increased number of active RCs of PSII and a higher $\varphi_{\mathrm{P} 0}$ in plants (Stirbet et al. 2018). This high vitality induced an improvement of PSII performance, which was confirmed by the $\mathrm{PI}_{(\mathrm{ABS})}$ values.

Alterations were also observed in the I-step $\left(\mathrm{V}_{\mathrm{I}}\right)$. Increased $V_{I}$ values can indicate changes in the efficiency/ probability of electron movement from PSII to the PSI acceptor side. This is because $V_{I}$ values lead to decreased values of $\psi_{\mathrm{R} 0}\left(=1-\mathrm{V}_{\mathrm{I}}\right)$. This parameter is sensitive to the effect of heavy metals and is associated with the significant decrease of PSI activity (Rastogi et al. 2019, Faseela et al. 2020). According to Küpper et al. (2019), a decline in $\psi_{\mathrm{R} 0}$ under heavy metal exposure can denote a decrease in the efficiency or probability of trapped electron transfer from PSII to PSI. In the present study, $\mathrm{Zn}$ exposure only caused a slight increase $(\sim 2.3 \%)$ of $V_{\text {I values in relation }}$ to the plants cultured without $\mathrm{Zn}$. Therefore, $\mathrm{Zn}$ in the concentration range tested did not induce a drastic decrease in PSI activity. In contrast, Se acted positively on the PSI activity, as shown by the $\varphi_{\mathrm{R} 0}$ values. Souza et al. (2019) suggested that Se mainly influences PSI functionality, and this element can enhance the electron transport dynamics from the intersystem to the PSI.

Besides the effects of $\mathrm{Zn}$ and $\mathrm{Se}$ on B. zebrina's physiology, these mineral elements also influenced the plant leaf anatomy. The plants grown with $\mathrm{Zn}$ exposure presented morphological traits indicating a higher potential for mineral uptake. The presence of heavy metals (at moderate concentrations) can stimulate an increase of stomatal density, as already reported for some plant species (Pereira et al. 2016, Pires-Lira et al. 2020), including other bromeliads (Martins et al. 2016, 2020). These authors observed quadratic behavior in relation to stomatal density, that is, the number of stomata increased as a function of heavy metal concentrations, followed by a decrease with supraoptimal concentrations. The number of stomata per area can regulate the transpiration rate and consequently the stomatal conductance (Pereira et al. 2016). Increased 
stomatal density induced by heavy metal exposure can increase stomatal conductance, enhancing $\mathrm{CO}_{2}$ uptake, possibly indicating tolerant plants. In addition, it can favor nutrient uptake by mass flow from the medium (Martins et al. 2019).

The traits of xylem vessels can also modulate hydraulic conductance and metal translocation under heavy metal stress conditions (Silva et al. 2012, Rodrigues et al. 2017, Cao et al. 2020). A larger number and/or diameter of xylem vessels can allow greater translocation and accumulation of heavy metals in the aerial part of plants (Cao et al. 2020, Martins et al. 2020). In contrast, a decrease in these xylem traits can avoid high uptake and translocation of metals (Rucińska-Sobkowiak 2016, Martins et al. 2019). Therefore, it was possible to note anatomical mechanisms that regulated the uptake and transport of $\mathrm{Zn}$ from the culture medium, allowing the plants to accumulate this metal. This also confirms that $\mathrm{Zn}$ (in the tested concentration range) did not negatively affect the $B$. zebrina plants. In addition, Se can enhance the modulation of those anatomical characteristics.

The nutritional status was associated with the plants' physiological responses. Plants grown under supraoptimal concentrations of $\mathrm{Zn}$ can present nutritional imbalance due to interference with other essential microelements (e.g., $\mathrm{Cu}$ and $\mathrm{Mn}$ ) by displacing other vital metallic ions located at the active sites of proteins, thus promoting physiological disorders (Sidhu 2016). This can occur because $\mathrm{Zn}$ has a similar ionic radius as bivalent cations, for instance $\mathrm{Cu}$. Hence, it can be absorbed by the same transporters and subsequently be translocated to the aerial part of plants (Tiecher et al. 2017). Still in relation to the $\mathrm{Cu}$ content, plants grown with Se supplementation had lower contents of this micronutrient. This response was correlated with Se source since under selenite supplementation, plants can present a decrease in $\mathrm{Cu}$ contents in their aerial parts (Pazurkiewicz-Kocot et al. 2008, Boldrin et al. 2013).

Nutrients such as Mn and $\mathrm{N}$ are structural components of Chl molecules, so their deficiency can negatively affect the photosynthetic apparatus (Mao et al. 2018, Roosta et al. 2018, Martins et al. 2019). Zinc excess had an antagonistic relationship with $\mathrm{N}$ and $\mathrm{Mn}$ contents. This influenced the Chl contents as well as the photosynthetic performance. Excess or deficiency of $\mathrm{Zn}$ can influence the nitrogen metabolism, leading to inefficient $\mathrm{N}$ assimilation and consequently inhibition of Chl formation (Sidhu 2016). Indeed, in this work, the lowest Chl content corroborated the lower $\mathrm{N}$ content. Moreover, $\mathrm{Mn}$ is associated with the production of oxygen from water during photosynthesis $\left(\mathrm{Mn}_{4} \mathrm{CaO}_{5}\right.$ complex) (Haider et al. 2006, Gururani et al. 2012). So, the decrease of Mn content may have minimized the PSII functionality and diminished the OEC integrity. In the present study, this was expressed as a lower functionality of the OEC, as inferred by the K-bands and $\mathrm{W}_{\mathrm{K}}$ values.

The lower $\mathrm{S}$ content observed in B. zebrina plants cultured with Se may be due to competition by using the sulfate pathway of the plants. Both S and Se share the same absorption site, besides having a competitive relationship for biochemical processes, such as assimilation into amino acids of essential proteins (Drahoňovský et al. 2016, Gupta and Gupta 2017). Those elements can decrease heavy metal stress by increasing the activity of glutathione, thus, in turn, reducing oxidative stress (Khan et al. 2015).

The co-exposure of Se with heavy metal has often been reported, and Se can reduce the effects of oxidative stress (Pereira et al. 2018, Chauhan et al. 2019, Wu et al. 2020). In the present study, the $B$. zebrina plants showed bioaccumulation capacity and tolerance to excess $\mathrm{Zn}$, irrespective of Se co-exposure; although only exhibiting slight physiological disturbances (e.g., total $\mathrm{Chl}$ and $\left.\mathrm{RC} / \mathrm{CS}_{0}\right)$. This response could be related to alterations in $\mathrm{H}_{2} \mathrm{O}_{2}$ and MDA contents, as reported by Jain et al. (2010) and Tiecher et al. (2017). The results clearly showed that Se relieved all stress levels induced by excess $\mathrm{Zn}$, in addition to improving plant performance. We suggest this occurred due to the protective role of Se by improved activation of the antioxidant system (Lin et al. 2012).

Conclusion: Both $\mathrm{Zn}$ and Se, alone or applied concurrently, affected the growth, anatomy, and physiology of $B$. zebrina plants during in vitro culture. High concentrations of $\mathrm{Zn}$ in the culture medium caused reduced biomass accumulation, besides physiological disorders, such as decreased photosynthetic pigments and the number of active RCs of PSII $\left(\mathrm{RC} / \mathrm{CS}_{0}\right)$. Se did not have a pronounced impact on nutritional status. Instead, $\mathrm{Zn}$ acted to modulate the nutritional status of $B$. zebrina plants. The exposure to Se enhanced the growth and photosynthetic apparatus performance. Moreover, Se also acted as a modulator to alleviate Zn stress. Billbergia zebrina plants can be used for biomonitoring due to their tolerance for excess $\mathrm{Zn}$ and the ability for bioaccumulation of this metal.

\section{References}

Abbasi S., Keshavarzi B., Moore F. et al.: Investigation of microrubbers, microplastics and heavy metals in street dust: a study in Bushehr city, Iran. - Environ. Earth Sci. 76: 798, 2017.

Andrejić G., Gajić G., Prica M. et al.: Zinc accumulation, photosynthetic gas exchange, and chlorophyll $a$ fluorescence in Zn-stressed Miscanthus $\times$ giganteus plants. - Photosynthetica 56: 1249-1258, 2018.

Arnon D.I.: Copper enzymes in isolated chloroplasts. Polyphenoloxidase in Beta vulgaris. - Plant Physiol. 24: 1-15, 1949.

Ashraf M.A., Akbar A., Parveen A. et al:: Phenological application of selenium differentially improves growth, oxidative defense and ion homeostasis in maize under salinity stress. - Plant Physiol. Bioch. 123: 268-280, 2018.

Aydoğan S., Erdağ B., Aktaş L.: Bioaccumulation and oxidative stress impact of $\mathrm{Pb}, \mathrm{Ni}, \mathrm{Cu}$, and $\mathrm{Cr}$ heavy metals in two bryophyte species, Pleurochaete squarrosa and Timmiella barbuloides. - Turk. J. Bot. 41: 464-475, 2017.

Benítez Á., Medina J., Vásquez C. et al.: Lichens and bromeliads as bioindicators of heavy metal deposition in Ecuador. Diversity 11: 28, 2019.

Bernardy K., Farias J.G., Pereira A.S. et al.: Plants' genetic variation approach applied to zinc contamination: secondary metabolites and enzymes of the antioxidant system in Pfaffia glomerata accessions. - Chemosphere 253: 126692, 2020.

Bochicchio R., Sofo A., Terzano R. et al.: Root architecture and 
morphometric analysis of Arabidopsis thaliana grown in $\mathrm{Cd} /$ $\mathrm{Cu} / \mathrm{Zn}$-gradient agar dishes: a new screening technique for studying plant response to metals. - Plant Physiol. Bioch. 91: 20-27, 2015.

Boldrin P.F., Faquin V., Ramos S.J. et al.: Soil and foliar application of selenium in rice biofortification. - J. Food Compos. Anal. 31: 238-244, 2013.

Cao Y., Ma C., Chen H. et al.: Xylem-based long-distance transport and phloem remobilization of copper in Salix integra Thunb. - J. Hazard. Mater. 392: 122428, 2020.

Cardoso-Gustavson P., Fernandes F.F., Alves E.S. et al.: Tillandsia usneoides: a successful alternative for biomonitoring changes in air quality due to a new highway in São Paulo, Brazil. Environ. Sci. Pollut. R. 23: 1779-1788, 2016.

Chauhan R., Awasthi S., Srivastava S. et al:: Understanding selenium metabolism in plants and its role as a beneficial element. - Crit. Rev. Environ. Sci. Technol. 49: 1937-1958, 2019.

Chen S., Kang Y., Zhang M. et al.: Differential sensitivity to the potential bioherbicide tenuazonic acid probed by the JIP-test based on fast chlorophyll fluorescence kinetics. - Environ. Exp. Bot. 112: 1-15, 2015.

Chen Y.E., Wu N., Zhang Z.W. et al.: Perspective of monitoring heavy metals by moss visible chlorophyll fluorescence parameters. - Front. Plant Sci. 10: 35, 2019.

Drahoňovský J., Száková J., Mestek O. et al.: Selenium uptake, transformation and inter-element interactions by selected wildlife plant species after foliar selenate application. Environ. Exp. Bot. 125: 12-19, 2016.

Faseela P., Sinisha A.K., Brestič M., Puthur J.T.: Chlorophyll $a$ fluorescence parameters as indicators of a particular abiotic stress in rice. - Photosynthetica 58: 293-300, 2020.

Georgiadou E.C., Kowalska E., Patla K. et al.: Influence of heavy metals $(\mathrm{Ni}, \mathrm{Cu}$, and $\mathrm{Zn})$ on nitro-oxidative stress responses, proteome regulation and allergen production in basil (Ocimum basilicum L.) plants. - Front. Plant Sci. 9: 862, 2018.

Giampaoli P., Tresmondi F., Lima G.P.P. et al.: Analysis of tolerance to copper and zinc in Aechmea blanchetiana grown in vitro. - Biol. Plantarum 56: 83-88, 2012.

Gupta M., Gupta S.: An overview of selenium uptake, metabolism, and toxicity in plants. - Front. Plant Sci. 7: 2074, 2017.

Gururani M.A., Upadhyaya C.P., Strasser R.J. et al.: Physiological and biochemical responses of transgenic potato plants with altered expression of PSII manganese stabilizing protein. Plant Physiol. Bioch. 58: 182-194, 2012.

Haghighi M., Sheibanirad A., Pessarakli M.: Effects of selenium as a beneficial element on growth and photosynthetic attributes of greenhouse cucumber. - J. Plant Nutr. 39: 14931498, 2016.

Haider S., Kanwal S., Uddin F., Azmat R.: Phytotoxicity of Pb II: changes in chlorophyll absorption spectrum due to toxic metal $\mathrm{Pb}$ stress on Phaseolus mungo and Lens culinaris. - Pak. J. Biol. Sci. 9: 2062-2068, 2006.

Handa N., Kohli S.K., Sharma A. et al:: Selenium ameliorates chromium toxicity through modifications in pigment system, antioxidative capacity, osmotic system, and metal chelators in Brassica juncea seedlings. - S. Afr. J. Bot. 119: 1-10, 2018.

Hou S., Zheng N., Tang L. et al.: Pollution characteristics, sources, and health risk assessment of human exposure to $\mathrm{Cu}, \mathrm{Zn}, \mathrm{Cd}$ and $\mathrm{Pb}$ pollution in urban street dust across China between 2009 and 2018. - Environ. Int. 128: 430-437, 2019.

Houri T., Khairallah Y., Al Zahab A. et al.: Heavy metals accumulation effects on the photosynthetic performance of geophytes in Mediterranean reserve. - J. King Saud Univ. Sci. 32: 874-880, 2020.

Jain R., Srivastava S., Solomon S. et al.: Impact of excess zinc on growth parameters, cell division, nutrient accumulation, photosynthetic pigments and oxidative stress of sugarcane (Saccharum spp.). - Acta Physiol. Plant. 32: 979-986, 2010.

Kalaji H.M., Bąba W., Gediga K. et al.: Chlorophyll fluorescence as a tool for nutrient status identification in rapeseed plants. Photosynth. Res. 136: 329-343, 2018.

Kalaji H.M., Jajoo A., Oukarroum A. et al:: Chlorophyll $a$ fluorescence as a tool to monitor physiological status of plants under abiotic stress conditions. - Acta Physiol. Plant. 38: 102, 2016.

Kalaji H.M., Schansker G., Brestic M. et al.: Frequently asked questions about chlorophyll fluorescence, the sequel. Photosynth. Res. 132: 13-66, 2017.

Khademi H., Gabarrón M., Abbaspour A. et al.: Environmental impact assessment of industrial activities on heavy metals distribution in street dust and soil. - Chemosphere 217: 695705, 2019.

Khan M.I.R., Nazir F., Asgher M. et al:: Selenium and sulfur influence ethylene formation and alleviate cadmium-induced oxidative stress by improving proline and glutathione production in wheat. - J. Plant Physiol. 173: 9-18, 2015.

Kumar V., Sharma A., Kaur P. et al.: Pollution assessment of heavy metals in soils of India and ecological risk assessment: A state-of-the-art. - Chemosphere 216: 449-462, 2019.

Küpper H., Benedikty Z., Morina F. et al.: Analysis of OJIP chlorophyll fluorescence kinetics and $\mathrm{Q}_{\mathrm{A}}$ reoxidation kinetics by direct fast imaging. - Plant Physiol. 179: 369-381, 2019.

Lin L., Zhou W., Dai H. et al.: Selenium reduces cadmium uptake and mitigates cadmium toxicity in rice. - J. Hazard. Mater. 235-236: 343-351, 2012.

Malavolta E., Vitti G., Oliveira S.A.: [Evaluation of the Nutritional Status of Plants: Principles and Applications.] Pp. 319. Potafos, Piracicaba 1997. [In Portuguese]

Mao Q.G., Lu X.K., Mo H. et al.: Effects of simulated N deposition on foliar nutrient status, $\mathrm{N}$ metabolism and photosynthetic capacity of three dominant understory plant species in a mature tropical forest. - Sci. Total Environ. 610611: 555-562, 2018.

Marques Junior A.N., Panetto D.P., Lamego F. et al.: Tracking atmospheric dispersion of metals in Rio de Janeiro Metropolitan region (Brazil) with epiphytes as bioindicators. An. Acad. Bras. Ciênc. 90: 2991-3005, 2018.

Martins J.P.R., Martins A.D., Pires M.F. et al.: Anatomical and physiological responses of Billbergia zebrina (Bromeliaceae) to copper excess in a controlled microenvironment. - Plant Cell Tiss. Org. 126: 43-57, 2016.

Martins J.P.R., Pasqual M., Martins A.D., Ribeira S.F.: Effects of salts and sucrose concentrations on in vitro propagation of Billbergia zebrina (Herbert) Lindley (Bromeliaceae). - Aust. J. Crop Sci. 9: 85-91, 2015.

Martins J.P.R., Rodrigues L.C.D.A., Silva T.D.S. et al.: Sources and concentrations of silicon modulate the physiological and anatomical responses of Aechmea blanchetiana (Bromeliaceae) during in vitro culture. - Plant Cell Tissue Org. Cult. 137: 397-410, 2019.

Martins J.P.R., Rodrigues L.C.D.A., Silva T.D.S. et al.: Morphophysiological responses of Aechmea blanchetiana (Bromeliaceae) to excess copper during in vitro culture. Plant Biosyst., 2020. doi: 10.1080/11263504.2020.1756976 (In press)

Martins J.P.R., Santos E.R., Rodrigues L.C.D.A. et al.: Effects of 6-benzylaminopurine on photosystem II functionality and leaf anatomy of in vitro cultivated Aechmea blanchetiana. - Biol. Plantarum 62: 793-800, 2018.

Monnet F., Vaillant N., Hitmi A., Sallanon H.: Photosynthetic activity of Lolium perenne as a function of endophyte status and zinc nutrition. - Funct. Plant Biol. 32: 131-139, 2005.

Murashige T., Skoog F.: A revised medium for rapid growth and 
bio assays with tobacco tissue cultures. - Physiol. Plantarum 15: 473-497, 1962.

Muszyńska E., Hanus-Fajerska E., Ciarkowska K.: Studies on lead and cadmium toxicity in Dianthus carthusianorum calamine ecotype cultivated in vitro. - Plant Biol. 20: 474482, 2018.

Paradisone V., Landi S., Esposito S.: Roles of silicon in alleviating zinc stress in plants. - In: Deshmukh R., Tripathi D.K., Guerriero G. (ed.): Metalloids in Plants: Advances and Future Prospects. Pp. 355-366. John Wiley \& Sons Ltd., Hoboken 2020.

Paunov M., Koleva L., Vassilev A. et al.: Effects of different metals on photosynthesis: Cadmium and zinc affect chlorophyll fluorescence in durum wheat. - Int. J. Mol. Sci. 19: 787, 2018.

Pazurkiewicz-Kocot K., Kita A., Pietruszka M.: Effect of selenium on magnesium, iron, manganese, copper, and zinc accumulation in corn treated by indole 3-acetic acid. Commun. Soil Sci. Plant Anal. 39: 2303-2318, 2008.

Pereira A.S., Dorneles A.O.S., Bernardy K. et al.: Selenium and silicon reduce cadmium uptake and mitigate cadmium toxicity in Pfaffia glomerata (Spreng.) Pedersen plants by activation antioxidant enzyme system. - Environ. Sci. Pollut. R. 25: 18548-18558, 2018.

Pereira M.P., Rodrigues L.C.A., Corrêa F.F. et al.: Cadmium tolerance in Schinus molle trees is modulated by enhanced leaf anatomy and photosynthesis. - Trees 30: 807-814, 2016.

Pires-Lira M.F., Castro E.M., Lira J.M.S. et al.: Potential of Panicum aquanticum Poir. (Poaceae) for the phytoremediation of aquatic environments contaminated by lead. - Ecotox. Environ. Safe. 193: 110336, 2020.

Rastogi A., Zivcak M., Tripathi D.K. et al.: Phytotoxic effect of silver nanoparticles in Triticum aestivum: Improper regulation of photosystem I activity as the reason for oxidative damage in the chloroplast. - Photosynthetica 57: 209-216, 2019.

Rodrigues L.C.A., Martins, J.P.R., Almeida Júnior O. et al.: Tolerance and potential for bioaccumulation of Alternanthera tenella Colla to cadmium under in vitro conditions. - Plant Cell Tiss. Org. 130: 507-519, 2017.

Roosta H.R., Estaji A., Niknam F.: Effect of iron, zinc and manganese shortage-induced change on photosynthetic pigments, some osmoregulators and chlorophyll fluorescence parameters in lettuce. - Photosynthetica 56: 606-615, 2018.

Rucińska-Sobkowiak R.: Water relations in plants subjected to heavy metal stresses. - Acta Physiol. Plant. 38: 257, 2016.

Santos L.R., Silva B.R.S., Pedron T. et al.: 24-epibrassinolide improves root anatomy and antioxidant enzymes in soybean plants subjected to zinc stress. - J. Soil Sci. Plant Nutr. 20: 105-124, 2020.

Sha S., Cheng M., Hu K. et al.: Toxic effects of $\mathrm{Pb}$ on Spirodela polyrhiza (L.): Subcellular distribution, chemical forms, morphological and physiological disorders. - Ecotox. Environ. Safe. 181: 146-154, 2019.

Sidhu G.P.S., Bali A.S., Singh H.P. et al.: Insights into the tolerance and phytoremediation potential of Coronopus didymus $\mathrm{L}$. (Sm) grown under zinc stress. - Chemosphere 244: 125350, 2020.

Sidhu G.P.S.: Physiological, biochemical and molecular mechanisms of zinc uptake, toxicity and tolerance in plants. J. Global Biosci. 5: 4603-4633, 2016.

Sidhu G.P.S., Singh H.P., Batish D.R., Kohli R.K.: Appraising the role of environment friendly chelants in alleviating lead by Coronopus didymus from Pb-contaminated soils. -
Chemosphere 182: 129-136, 2017.

Silva N.D.G., Cholewa E., Ryser P.: Effects of combined drought and heavy metal stresses on xylem structure and hydraulic conductivity in red maple (Acer rubrum L.). - J. Exp. Bot. 63: 5957-5966, 2012.

Singh S., Parihar P., Singh R. et al.: Heavy metal tolerance in plants: role of transcriptomics, proteomics, metabolomics, and ionomics. - Front. Plant Sci. 6: 1143, 2016.

Singh S., Singh A., Srivastava P.K., Prasad S.M.: Cadmium toxicity and its amelioration by kinetin in tomato seedlings vis-à-vis ascorbate-glutathione cycle. - J. Photoch. Photobio. B 178: 76-84, 2018.

Souza A.F.C., Martins J.P.R., Gontijo A.B.P.L., Falqueto A.R.: Selenium improves the transport dynamics and energy conservation of the photosynthetic apparatus of in vitro grown Billbergia zebrina (Bromeliaceae). - Photosynthetica 57: 931-941, 2019.

Souza S.C., Souza L.A., Schiavinato M.A. et al.: Zinc toxicity in seedlings of three trees from the Fabaceae associated with arbuscular mycorrhizal fungi. - Ecotox. Environ. Safe. 195: 110450, 2020.

Stirbet A., Lazár D., Kromdijk J., Govindjee: Chlorophyll $a$ fluorescence induction: Can just a one-second measurement be used to quantify abiotic stress responses? - Photosynthetica 56: 86-104, 2018.

Strasser R.J., Tsimilli-Michael M., Srivastava A.: Analysis of the chlorophyll $a$ fluorescence transient. - In: Papageorgiou G.C., Govindjee (ed.): Chlorophyll $a$ Fluorescence: A Signature of Photosynthesis. Advances in Photosynthesis and Respiration. Pp. 321-362. Springer, Dordrecht 2004.

Tiecher T.L., Tiecher T., Ceretta C.A. et al:: Tolerance and translocation of heavy metals in young grapevine (Vitis vinifera) grown in sandy acidic soil with interaction of high doses of copper and zinc. - Sci. Hortic.-Amsterdam 222: 203-212, 2017.

Wang Y.W., Xu C., Lv C.F. et al.: Chlorophyll $a$ fluorescence analysis of high-yield rice (Oryza sativa L.) LYPJ during leaf senescence. - Photosynthetica 54: 422-429, 2016.

Wu C., Dun Y., Zhang Z. et al.: Foliar application of selenium and zinc to alleviate wheat (Triticum aestivum L.) cadmium toxicity and uptake from cadmium-contaminated soil. Ecotox. Environ. Safe. 190: 110091, 2020.

Yin H., Qi Z., Li M. et al.: Selenium forms and methods of application differentially modulate plant growth, photosynthesis, stress tolerance, selenium content and speciation in Oryza sativa L. - Ecotox. Environ. Safe. 169: 911-917, 2019a.

Yin Z., Lu J., Meng S. et al.: Exogenous melatonin improves salt tolerance in tomato by regulating photosynthetic electron flux and the ascorbate-glutathione cycle. - J. Plant Interact. 14: 453-463, $2019 b$.

Zampieri M.C.T., Saiki M., Tavares A.R. et al.: [Accumulation of mineral nutrients in Aechmea blanchetiana (Baker) L.B. Smith (Bromeliaceae) contaminated with zinc during in vitro culture.] - Hoehnea 39: 379-385, 2012. [In Portuguese] doi: 10.1590/S2236-89062012000300003

Zhang H.H., Xu N., Wu X. et al.: Effects of four types of sodium salt stress on plant growth and photosynthetic apparatus in sorghum leaves. - J. Plant Interact. 13: 506-513, 2018.

Zhao Y., Hu C., Wang X. et al.: Selenium alleviated chromium stress in Chinese cabbage (Brassica campestris L. ssp. Pekinensis) by regulating root morphology and metal element uptake. - Ecotox. Environ. Safe. 173: 314-321, 2019.

(C) The authors. This is an open access article distributed under the terms of the Creative Commons BY-NC-ND Licence. 